\title{
Dört asır dört şair bağlamında divan edebiyatında dünya algısı
}

\section{Halime ÇAVUŞOĞLU1}

\begin{abstract}
APA: Çavuşoğlu, H. (2019). Dört asır dört şair bağlamında divan edebiyatında dünya algısı. RumeliDE Dil ve Edebiyat Araşttrmaları Dergisi, (14), 224-240. DOI: 10.29000/rumelide.541014
\end{abstract}

\section{$\ddot{O} \mathbf{z}$}

Divan edebiyatında çoğunlukla dinî ve tasavvufî bakış açısıyla değerlendirilen dünya kavramı, yüzyıllar boyunca çok farklı unsurlarla sembolize edilmiş, çoğu zaman fiziki ve coğrafi bir varlık olmaktan ziyade insanların ona yüklediği anlamlarla değerlendirilmiştir. Bu da dünya kavramının ahlaki bir kavram olarak ele alınmasına zemin hazırlamıştır. Bu anlayıştan dolayı edebî metinlerde dünya, çoğunlukla uzak durulması gereken bir unsur olarak telakki edilmiştir ve dünya kavramına ilişkin yapılan benzetmeler de bu doğrultuda çoğunlukla olumsuz nitelikte olmuştur. Edebî metinlerde, kimi zaman bir oyun yeri, kimi zaman bir pazar, kimi zaman bir acuze, kimi zaman da bir yılan olarak algılanan dünyanın vefasızlığına, dönekliğine, kararsızlığına da ayrıca dikkat çekilmiştir. $\mathrm{Bu}$ çalışmada öncelikle dünya kavramının Kur'an-ı Kerim ve hadislerde genel itibariyle nasıl değerlendirildiği ifade edilecek, ardından ilk dönem İslâmî ürünlerinden alınan metinlerle çalışma örneklendirilecektir. Bu bağlamda divan şiirinin büyük şahsiyetlerinin yetiştiği 15., 16., 17. ve 18. yüzyıllardan tespit edilen şairlerin divanlarında dünya kavramına yönelik var olan beyitler taranıp divan şairinin dünya algısına yönelik tespitler yapılmaya çalışılacaktır. Çalışmada değerlendirmeler üç başlık altında ele alınacaktır. Öncelikle dünya kavramına yönelik benzetmeler seçilen şairler noktasında tespit edilecek, akabinde metinlerde dünyanın niteliklerine dair yapılan göndermeler örneklendirilerek insanların dünya ve dünya hayatına dair alması gereken tedbirler şair gözüyle sunulacaktır. Bu zeminde divan edebiyatında dünya algısına dair tespitler dört asır ve dört şair bağlamında değerlendirilecektir.

Anahtar kelimeler: Divan edebiyatı, divan şiirinde dünya, tasavvuf, divan.

\section{The perception of the world in divan literature in the context of four centuries and four poets}

\begin{abstract}
The concept of the world, which is mostly evaluated in religious literature from the religious and mystical point of view in Divan literature, has been symbolized by many different elements over the centuries, and has often been evaluated by the meaning attributed to it by people rather than as a physical and geographic entity. This has paved the way for the concept of the world as a moral concept. Because of this understanding, the world in literary texts is mostly considered as an element that needs to be avoided and the analogies made about the concept of the world are mostly negative in this direction. In literary texts, the world's hypocrisy, betrayal and instability, which can be perceived as sometimes a game place, sometimes a market, sometimes a grumpy woman and sometimes a snake, have also been pointed out. In this study, firstly how the concept of world is evaluated in the Quran and Hadith-Sharifs will be explained, then the study will be exemplified using
\end{abstract}

$1 \quad$ Dr. Öğr. Üyesi, Erzurum Teknik Üniversitesi, Edebiyat Fakültesi, Türk Dli ve Edebiyatı Bölümü, (Erzurum, Türkiye), cavusogluhalime@erzurum.edu.tr, ORCID ID: o000-0001-8717-5679 [Makale kaylt tarihi: 07.02.2019-kabul tarihi:13.0.2019; DOI: 10.29000/rumelide. 541014] 


\begin{abstract}
the works taken from the first period Islamic products. Poets from the 15th, 16th, 17th and 18th centuries, in which the great personalities of the divan poetry were raised, will be selected and conclusions about the world perception of the divan poet will be drawn by scanning the couplets existing for the concept of the world in the selected poet's divans. In this study, the evaluations will be discussed under three headings. Firstly, the comparisons for the concept of the world will be determined for the chosen poets, then the references in the texts about the qualities of the world will be exemplified and finally the measures that people should take on the world and world life will be presented from the perspective of the poets. The determinations of world perception in divan literature will be evaluated in the context of four centuries and four poets.
\end{abstract}

Key words: Divan literature, world in divan poetry, mysticism, divan.

\title{
Giriş
}

Edebî metinlerde çoğu zaman zemin, cihan, âlem isimlendirmeleriyle karşımıza çıkan dünya kavramı terimsel, tasavvufî ve edebî olarak farklı tanımlamalarla değerlendirilmektedir. Türk Dil Kurumu Sözlüğü'nde "üzerinde yaşadığımız toprak ve denizler, yeryüzü2" şeklinde tanımlanan kavramın metinlerde özellikle dinî-tasavvufî ve kültürel yönleriyle kullanıldığı dikkat çekmektedir.

Tasavvufî̀ olarak Cebecioğlu tarafından "Arapça yakın, alçak gibi lügat anlamlarına karşıllk, üzerinde yaşadığımız şu gezegenin adıdır. Tasavvufta, dünya çeşitli şekillerde tanımlanmıştır: 1-Seni Allah'tan alıkoyan her şey, 2-İmtihan yeri, 3-Ahiretin tarlası, 4-Geçici, fani yer. Dünya ile ilgili olarak dervişler: 'Yalan dünya', 'yalancı dünya', 'dünya malı dünyada kalır.' demişlerdir. Dünya ayrıca cadı, yılan, zehir ve fahișeye benzetilmiștir (1997: 229)." șekillerinde tanımlanan kavram, Uludağ tarafından "yakın olmak mânasına gelen dünüv kökünden türemiş 'en yakın' anlamındaki ednâ kelimesinin müennesidir. Kur'an'da ahiret ve ahiret hayatının karşılı̆̆ olmak üzere çok defa, "yakın hayat" anlamındaki el-hayâtü'd-dünyâ tamlamasında hayat kelimesinin sıfatı olarak, bazen de belirli (mârife) şekliyle isim olarak kullanılmıştır. Hadislerde ise belirsiz (nekre) olarak da geçer. Bu yakın hayatın ardından gelecek olan hayata, "sonraki hayat" anlamında ahiret adı verilmiştir (1994: 22)." ahiretle olan ilişkisi bağlamıyla değerlendirilmiştir.

Kur'an-ı Kerim'de3 geçici bir oyun yeri, hadislerde müminler için bir zindan, insanlar için bir sihirbaz hatta Hak katında bir sineğin kanadı kadar değersiz olarak gösterilen dünya, ahiret hayatının hazırlık mekânı olması ve sonsuz hayatın saadetinin burada sürdürülen hayata bağlı olması noktasında önemli addedilmiştir. Dünya hayatının geçiciliğine yönelik ayet ve hadislerden birkaç tanesini şöyle siralayabiliriz:

Bilin ki dünya hayatı, bir oyun, bir eğlence, bir gösteriş, aranızda bir övünme, mal ve evlâtta bir çokluk yarışından ibarettir. Tıpkı bir yağmur gibi ki bitirdikleri çiftçileri imrendirir, sonra kurumaya yüz tutar, bir de bakarsın ki sararmıştır, ardından da çer çöp haline gelmiştir. Âhirette ise ya çetin bir azap yahut Allah'ın bağışlaması ve hoşnutluğu vardır. Dünya hayatı sadece aldatıcı bir yararlanmadan başka bir şey değildir (Hadid, 57/20).

(Oysa onların tek gerçek kabul ettikleri) bu dünya hayatı hakikatte sadece bir oyun ve eğlenceden ibarettir; âhiret yurduna gelince işte asıl hayat odur; keşke bunu bilselerdi (Ankebut, 29/64)!

Dünya hayatı oyun ve eğlenceden ibarettir. Siz iman eder ve Allah'a itaatsizlikten sakınırsanız O da hak ettiğiniz karşllı̆̆ verecek, sizden servetinizi de istemeyecektir (Muhammed, 47/36).

bkz. http://www.tdk.gov.tr

Ayet mealleri, https://kuran.diyanet.gov.tr/tefsir adresinden alınmıştır. 
Dünya müminin zindanı, kâfirin cennetidir (İmam Nevevi, 2016: 444).

Âhiretin yanında dünyanın değeri, ancak sizden birinizin parmağını denize daldırmasına benzer. Parmağı ile denizden alabildiği suya bir baksın (İmam Nevevi, 2016: 439).

Dünyadan sakının! Zira o insanları sihirleri ile etkileyen Hârût ve Mârût'tan daha büyük sihirbazdır (Gazali, 2003: 221)!

Yukarıda da ifade edildiği gibi dünya hayatı salih ameller işleme noktasında bir firsattır ve insan bu firsatı iyi değerlendirmelidir. Ayrıca İslâm'da dünya nimetlerinden istifade etmek yasaklanmamıştır. Dünya hayatı Kur’an'da genellikle ahiret hayatı ile birlikte anılmış, bazen ikisi arasında karşılaştırma yapılarak ahiret hayatının üstün olduğu belirtilmiştir. "Kur’an’a göre, âhiret için amelleri engellemeyen ve aksatmayan dünya hayatı meşrû bir nimet, hatta saadettir ( Uludă̆, 1994: 22)." A'râf Suresi 32. ayette de şöyle zikredilmektedir: "De ki: Allah'ın kulları için yarattığı süsü ve temiz rızıkları kim haram kıldı? De ki: Onlar dünya hayatında müminlere yaraşır; kıyamet gününde ise yalnız onlara mahsus olacaktır."

Diğer taraftan dinî-tasavvufî kaynaklarda, peygamber kıssalarında, evliya enbiya menkıbelerinde dünya hayatının ahiret hayatı karşısındaki değersizliği ve geçiciliği birkaç örnekle şöyle dile getirilebilir:

Cebrail, Hz. Nuh'a sorar:

-Ey peygamberlerin en uzun ömürlüsü, dünyayı nasıl buldun?

Hz. Nuh şöyle cevap verir:

İki kapılı bir ev gibi; birinden girdim diğerinden çıktım (Gazali, 2003: 220).

Hz. Lokman oğluna şöyle bir nasihatte bulunur:

Yavrucuğum, dünya engin derinlikte bir deryadır. Orada çok insanlar boğuldu. O engin denizde takvayı kendine gemi edin. Gemiye yükleyeceğin eşya Allah Teala'ya iman olsun. Geminin yelkeni de Allah'a tevekkül etmek olsun. Böyle yaparsan belki kurtuluşa erersin, başka da kurtuluş yolu görmüyorum (Gazali, 2003: 227).

Gazali, Allah'ın Hz. Musa'ya şöyle vahyettiğini ifade eder:

Ey Musa! Zalimler yurdu dünyadan sana ne! Orası sana göre yurt değil. Dünya ile ilgili endişelerden kurtul, aklını o anlayıştan kurtar. Dünya ne kötü bir yurttur. Ama dünyada salih ameller işleyenler için öyle değil! Onlar için ne iyi yurttur. Ey Musa! Ben mazlumun hakkını alıncaya kadar zalimi tarassut altında tutarım (2003: 222).

Meşhur âlim ve zahit Hasan-ı Basrî kendisine kulak verenlere dünyanın geçiciliği üzerine şöyle seslenmiştir:

Ey, Âdemoğlu yapayalnız öleceksin, yapayalnız gireceksin mezara, yapayalnız dirileceksin ve yapayalnız hesap vereceksin! Öyleyse bu yalancı dünyaya neden tamah etmeli? Bu dünyaya hiç gelmemişsin ahireti ise hiç terk etmeyecekmişsin gibi düşün (Schimmel, 2001: 45).

Bağdatlı mutasavvıf Şiblî dünya ve dünyalığın Hak ile bir engel olduğunu şu şekilde ifade eder:

Dünyayı da ahreti de emrime amade kıl, ta ki dünyayı bir lokma yapıp bir köpeğin ağzına atayım, ahreti de bir lokma haline getirip bir Yahudi'nin ağzına koyayım. Zira her ikisi de maksut [amaç] için hicaptır [engeldir] (Schimmel, 2001: 54).

Tasavvufta dünya kavramına bakış ona yüklenen anlamla değerlendirilmiş ve dünya, çoğunlukla fiziki ve coğrafi bir mekân olarak değil, ahlaki bir kavram olarak açıklanmıştır: "... tasavvuftaki dünya kavramını, bugün anlaşılan dünya tanımlarından ayıran şey, değer perspektifli bakıştır. Buna göre 
kötü olan dünyanın bizatihi kendisi değil, kişideki dünya algısı, dünyanın insan için ifade ettiği anlamdır. Başka bir deyimle, insanın şuur/bilinç aleminde işgal ettiği yerdir (Erginli, 2006: 128)." Uludağ'ın da ifade ettiği gibi dünyaya bakış açısı "Böylece insan dinî bir şuurla, dünyaya mahkûm olmak yerine ona hâkim olduğu ve onları yönlendirdiği, dünyevî varlık ve imkânları Allah'in rızâsına ve kendi âhiret saadetine uygun şekilde kullandiğı sürece bu varlk ve imkânlar kötülenen dünyadan değildir. İnsanın maddeye mahkûm ve bağıml olması dünyadır, ancak ona hâkim olması dünya değildir. Maddenin önde ve üstün tutulması dünya, mânanın önde ve üstün tutulması âhirettir. Şu halde dünya, ruhla nesneler arasındaki sağhlkszz ve olumsuz ilişkiden ibarettir (1994: 24)." ya da Erginli'nin değindiği gibi "... kötü olan dünyanın kendisi değil, insanın yaratılışında bulunan kolaylıkla maddeye/dünyaya kapılmaya yol açabilecek eğilimlerdir. Bu durum, temelde insanın gerek maddi ve gerekse manevi açıdan ihtiyaç sahibi bir varlık olması ve bu muhtaçlkk durumunun farkında bulunmasıyla da sıkı sıkıya ilişkilidir (2006: 173)." açılamalarıla değerlendirilebilir. Zira Hak âşıkları için dünya, kötülenip uzaklaşılacak bir mekân değil; Hakk'ın tecelligâhıdır. Dünyayı İlahî güzelliğin yansıması olarak görenler için bu mekân, Hakk'a ulaşmada bir engel değil, onun güzelliklerini yansıtan bir ayna hatta ona ulaşmada bir vasıtadır.

Edebiyatımızda da dünyanın geçiciliğine, aldatıcılığına, göz boyayıcılı̆̆ına yönelik değerlendirmeler, ilk İslâmî ürünlerle baskın bir şekilde kendisini göstermeye başlamış, asırlar boyunca da mutasavvıf, âlim ve şairler tarafından bu bakış açısıyla insanlar, iyiye ve doğruya yönlendirilmeye çalışılmıştır. Kutadgu Bilig'de4 hükümdar Kün Togdı hakkındaki bölümün girişinde dünya ile ilgili sadeleştirilmişs şekliyle şu ifadelere yer verilmiştir:

Bu kocakarı dünya vefasız ve dönek huyludur;

edası kız gibidir, ama bakarsın yaşı büyüktür.

Bazen edası kız gibidir, tavırları güzeldir, kendini sevdirir

fakat tutmak istedin mi elini vermez

Seveni sevmez ondan geyik gibi kaçar;

kaçana yapışır, onun ayağına sarılır.

Bir bakarsın, süslenip kuşanarak arkandan koşar;

bir bakarsın, görmezlikten gelir, önüne bakar.

Bir bakarsın, yine yüzünü çabucak çevirir, nazlanır;

ne kadar yakalamak istersen el sürdürmez.

O çok beyleri yaşlandırdı, kendisi yaşlanmaz;

çok beyleri göçürttü, hiç susmak bilmez

(Kutadgu Bilig: 399/404).

Dünyaya yönelik bu bakış açısı 13. yüzyılda yaşamış, eserleri ve düşünce sistemiyle dünya çapında bir üne sahip âlim, mutasavvıf, mütefekkir, şair Mevlânâ'da üst düzeyde kendini göstermiştir. Dünyanın

Kutadgu Bilig'den alınmış beyitler, Yusuf Has Hacip, (2008), Kutadgu Bilig, Çev. Reşid Rahmeti Arat, Kabalcı Yayınevi, İstanbul, s. 151-153'ten alınmış̦tır. 
maddî bir varlık olarak değerlendirilmediği Mevlânâ'ya göre dünya "... ne para, ne kumaş ve ne de kadındır. Dünya Hak Teâlâ'dan gaflettir. Yani insanı Hak'tan, hakikat bilgisinden, ebedi mutluluğa giden yoldan engelleyen her şeydir. Böyle bir dünya ise insan için karanliktır, kapal bir zindandır. Keza, dar olduğu için insanı iki büklüm hale sokan bu dünya Mevlânâ tarafindan bir berzah âlemi olarak tavsif edilerek sönmeyen ışığın, gerçek âlemin onun ötesinde olduğu beyan edilmiştir (Yetik, 1992: 102)." Mesnevî'de dünyanın ehl-i dünyaya hal diliyle nasihati şu şekildedir: "Bu kevn ü fesad âleminden murad, oluş, hile ve bozuluş da nasihattir. Oluş, sana 'Gel ben pek güzelim' bozuluş da 'Benden sakın, ben bir şey değilim!' der. Ey baharın güzelliğine hayran kalıp dudağım ısıran, sonbaharı soğukluğuna, sarllğına bak! Gündüzün güneşin yüzünü görürsün ama bir de gurub zamanı onun ölümünü düşün! Dolunayı gökleri süsler görürsün ama onun son günlerindeki hasretine dikkat et! Çocukken insan, güzelliğiyle halkın dikkatini çekerken kocayınca bu bakımdan itibarı kalmaz (Çelebioğlu, 1969: IV/63). Önce böyle oluşa dikkat et, sonunda onlartn değişerek bozuluşunu hatırla! Sana dünya, tuzağın göstermede; ona kapılan hamların da bıyığını yolmada! 'Eyvah, dünya bana hile etti! Yoksa aklım, bilgisiyle ondan kurtulurdu!' deme! Gerçekte bir demir toka ve zencir olan bă̆ ve tuzağın altın halkasın ve hamâyilini iyice gör! Bütün âlemin cüzleri de böyledir; onlarm evveline, âhirine bak (Çelebioğlu, 1969: IV/63)!" Mesnevi'de evrenin ve evrende yaşayanların var oluş ve bozuluşunun bir sirkülasyon halinde devam ettiği ifade edilerek insanların dünyanın sonunu görebilmelerine dünya diliyle dikkat çekilmiştir. Aynı asrın bir başka mutasavvıf şairi Yunus Emre de bir manzumesinde aynı var oluş ve bozuluşu; başlangıç ve sonu şöyle dile getirir:

Bu dünyânun meseli bir ulu şâra benzer

Velî bizüm ömrümüz bir tîz bâzâra benzer

Her kim bu şâra geldi bir lahza karâr kıldı

Girü dönüp gitmeği gelmez sefere benzer

Bu şârun evvel dadı şehd ü şekerden şîîn

Âhir acısını gör şu zehr-i mâra benzer

Evvel gönül almagı hûblara nisbet eder

Âhir yüz döndürmegi acûz mekkâra benzer

(Tatcl, 2012: 172).

Dünyanın büyük ve eski bir şehre benzetildiği manzumede, insan ömrü bu koca şehirdeki konup göçen bir pazara benzetilerek ömrün geçiciliği "tîz" sıfatıyla nitelenmiştir. Manzumedeki evvel ve ahir ifadeleriyle de önce görünen güzelliklerin sonra bozuluşuna değinilmektedir. Kısacası aynı görüş, iki büyük şahsiyetin gözüyle aynı doğrultuda dile getirilmektedir. Zira divan edebiyatında dünya kavramıla bütünleştirilen Yunus'ta "acûz mekkâr" ifadesi ile dile getirilen "hilekâr, düzenbaz kocakarı" tamlaması Mevlânâ'nın "Şehzâde ile Büyücü Kadının Hikâyesi"nde şu şekilde kendisini gösterir: "Rüyasında çeşit çeşit hünerlerle bezeli şehzadesinin öldüğünü gören kudretli bir padişah, bu sıkıntılı durumu hayra yorar ve şehzadesi ölse bile ondan bir hatıra kalması için onu evlendirmeye karar verir. Fakat bu evlilikte amacı iyi soylu bir kız almaktır ve bunun için de bir padişah kızını değil soyu temiz bir zahidin kızını seçer. Bütün itirazlara rağmen de şehzadesini temiz soylu bu kız ile evlendirir. Fakat şehzade, kendisine âşık olan büyücü kocakarının büyüsüyle kocakarının âşığı olur ve onun peşinden sürüklenir, gider. Bu hal bir başka büyücünün büyüyü bozarak şehzadenin eski halini almasına yardım edene dek devam eder. "Kısa özetini verdiğimiz Mesnevî'nin bu hikâyesinin sonunda şehzadenin 
insanoğlunu, babasının Hz. Âdem'i, büyücü kocakarının dünyayı ve ona çare bulan tabibin de peygamberler ve evliyaları sembolize ettiğine yönelik şöyle bir tespit yapılmıştır: "A kardeş, bil ki o şehzade sensin; bu köhne dünyaya gönül vermişsin! Kâbilli büyücü, bu dâr-ı dünyâdır; yiğitleri bile kokusuna esir etmiştir! Onun büyüsü sana tesir etmeye başlayınca her an duan 'Kul eûzü' olsun. Ta ki sabahın Rabb'inden yardım dileyip gamdan, gönül darlı̆ından kurtulasın. Bu sebepten $\mathrm{Hz}$. Peygamber, halkı, büyü ve efsunuyla aldattı̆̆ için dünyaya kocakarı demiştir (Çelebioğlu, 1969: IV/122-123 )." Mesnevî hikâyelerinde bu örneğin dışında dünyanın zindan, ağaç vb. farklı unsurlarla sembolize edildiği tespit edilmiştir.

Bu minvalde edebî metinlerde yüzyllar boyunca dünya kavramı çok farklı unsurlarla sembolize edilmiş ve yeri geldikçe şairler tarafından dünyanın vasıflarına yönelik göndermelerde bulunularak dünyaya ve dünya hayatına karşı takınılması gereken tavırlar sıralanmıştır. Bu çalışmada da divan şairinin dünya algısına yönelik tespitler yapabilmek için divan şiirinin büyük şahsiyetlerinin yetiştiği 15., 16., 17. ve 18. yüzyıllardan birer şair seçilmiş, ilgili şairlerin divanları dünya, dehr, zemin, cihan, âlem kelimeleri dikkate alınarak baştan sona kadar taranmıştır. Ele geçen malzemeler, benzer durumları ifade edenler arasından ilgili duygu ve düşünceyi yansıtması açısından birkaç beyit örnek alınarak değerlendirmeye tabi tutulmuştur. 15. yüzyıldan Şeyhî, 16. yüzyıldan Bâkî, 17. yüzyldan Şeyhülislam Yahya ve 18. yüzyıldan Şeyh Galib'in ${ }^{5}$ divanlarından seçilen beyitler üç başlık altında incelemeye alınmıştır:

\section{Dünyanın Benzetildiği Unsurlar}

\section{Dünyanın Nitelikleri}

\section{Dünyaya Karşı Takınılması Gereken Tavır}

\section{Dünyanın benzetildiği unsurlar}

Dünya sıkıntı, dert, elem sarayıdır, bir an güzellikler yaşansa da çoğu zaman sıkıntı çekilir:

Mihnet-sarây-ı dehre gelüp 'ayş u nûş iden

Bir dem hoş olsa bir nice gün derd-i ser çeker

(Bâkî Divanı G163/3)

Dünya geçici, imar edilemeyecek kadar harap, belanın yağmur gibi yağdığı viran ve köhne bir saraydır. Bu menzili kimse tamir edemez ve bu fani saray sürekli el değiştirir:

Cây-ı âsâyiş olur sanma cihân-ı fânî

Eyleme kasd-ı 'imâret bu harâb eyvânı

Menzil-i bâr-ı belâ kühne-serâdur dünyâ

Künc-i râhat yiri zann eyleme bu vîrânı

Felegüñ kasr-ı dil-âvîine meftûn olma

Nice mîrâsa girüpdür bu sarây-ı fânî

(Bâkî Divanı Mer. 2,I/1,2,3)

Yapılan incelemelerde kullanılan beyitler șu kaynaklardan alınmıștır: Mustafa İsen, Cemal Kurnaz, Seyhî Divanı, Ankara, Akçağ, 1990; Sabahattin Küçük, Bâkî Dîvânı, Türk Dil Kurumu Yayınları, Ankara, 1994; Rekin Ertem, Yahyâ Divanı, Ankara, Ankara, Akçağ, 1995; Muhsin Kalkışım, Şeyh Gâlib Dîvânı, Ankara, Akçağ, 1994. 
Aynı zamanda dünya, kendisine bel bağlanmayacak bir mekândır, zira en ufak bir sarsıntıda yerle bir olur:

Şeyhî bekâ diler isen cân haremin imâret et

Kim bu cihân meremmeti hey demedin harâb olur

(Şeyhî Divanı G69/12)

Dünya her taraftan inlemelerin yükseldiği, sıkıntıların çekildiği, haksızlıkların yapıldığı bir geçici pazar yeridir:

Kaçan mestâne gezsen çâr-sûy-ı dehri ey Bâkî

Olur ol demde peydâ her tarafdan nâleler yir yir

(Bâkî Divanı G19o/5)

Bâkî metâ'-1 nazm ile bâzâr-ı dehrde

Cevr-i li'âm u mihnet-i eyyâm sûdumuz

(Bâkî Divanı G193/5)

Dünya pazarında âşıklığı geçerli olan âşığın isteği, alıcısının sevgili olmasıdır:

Kâsid et bâzâr-1 âlemde metâ'-1 râ'icim

Ya'nî senden gayri hiç kimse harîdâr olmasın

(Şeyh Gâlib Divanı Müf. 56)

Âşıkların inlemeleri ile dolu olan dünya hankâhı bu özelliği ile tıpkı bir matem yeri gibidir:

Hânkâh-ı dehr toldı nâle-i 'uşşâkdan

Câygâh-1 şiven ü menzilgeh-i mâtem gibi

(Yahyâ Divanı G419/4)

Bazen de talihin ters gittiği bir mamuredir:

Dehr ma'mûresi emrindeyiken tâlî'i gör

Yıktı gönlüm evini hükmü bu vîrâna geçer

(Şeyhî Divanı G22/4)

Gaflet içerisindeki insanoğlu bu dünya acuzesine âşık olup durmaktadır; ama onun yakınlığı binlerce bahtlı şahı yok etmiştir:

Bu pîre-zen-i dehri ki ma'şûk edinirsin

Bin şâh-ı cüvan-bahtı yele verdi velâsı

(Şeyhî Divanı K6/10)

Dünya hilesine aldanmamak gereken bir kocakarı gibidir ki mert olan ondan uzak durur:

Merd isen dehr-i denî mekrine meftûn olma

Er odur kim vire bu pîre-zen-i dehre talâk

(Bâkî Divanı G232/4)

Bâkî 'acûz-ı dehre er olmaz zebûn olan

Merdân-ı râh-ı 'aşk dimezler ana racül

(Bâkî Divanı G304/5)

Pîre-zâl-i dehre Bâkî kimse muhtâc olmasun

Saklasun Hak kulların nâ-merde muhtâc olmadan

(Bâkî Divanı G394/5)

Bâkî 'acûz-ı dehre zebûn olma key sakın 
Mürîd-i 'aşk oldum ben tecerrüd ihtiyâr itdüm

Eger meyl eyler isem bir zen-i dünyâya nâ-merdüm (Bâkî Divanı G344/4)

Dünya nimetlerine karşı kanaatkâr olan Hak dostu, bu acuze dünyaya hiçbir zaman kapılmaz, zira Hakk'ın dostluğu her şeye bedeldir:

Hemân nakd-i hayât-i bî-dirîg iken anın mihri

Zen-i dünyâya Gâlib râm olur mu merd-i istignâ

(Şeyh Gâlib Divanı G1o/6)

Gönül, dünya acuzesine gaflet şarabını içmedikçe meyil vermez:

Mâ'il olmaz dil zen-i dünyâya bir hûb anlayup

Bâde-i gafletle medhûş olmayan itmez galat

(Yahyâ Divanı G167/4)

Dünya, öyle bir efsanedir, öyle bir hayaldir ki onda çekilen üzüntü ve duyulan mutluluklar rüya gibi gelip geçicidir:

Cihân efsânedür aldanma Bâkî

Gam u şâdî hayâl-i hâba benzer

(Bâkî Divanı G116/5)

Gerçekte dumanlı bir ateş olan dünya, görüntüde güzel, süslü, kubbeli bir köşktür:

Ma'nîde bir dûd peydâ kılmış âteşdür cihân

Sûretâ bir hûb kâşî kubbelü kâşânedür

(Bâkî Divanı G136/4)

Dünya yedi başlı ejderha olarak tanımlanan felek tarafından sarmalanmış bir hazinedir:

Felek bir ejdehâ-yı heft-serdür

Tolanmış genc-i dünyâyı ser-â-pây

(Bâkî Divanı G519/2)

Dünya açıp solan, kimseye fayda vermeyen, uğruna çekilen sıkıntı ve eziyetlerin boşuna olduğu bir güldür, yani kokusu uğruna dikenine katlanmak boşunadır:

Dirîgâ gül-i dehr hârına değmez

Felek humm hamrı humârına değmez

(Şeyhî Divanı G82/1)

Gönül umma dünyâ gülünden koku kim

Yüzü anun âh-ı hezârına değmez

(Şeyhî Divanı G82/3)

Kimi beyitlerde de gülüne ulaşlamayan bir dikenliktir:

Gül-i maksûdı il buldı benüm zâr oldıgum kaldı

Bu hâristân-ı 'âlemde dil-efkâr oldıgum kaldı

Dünya, uğruna çabalamaya değmeyecek bir hazinedir:

Bu gencîneden gözleme nûş-dârû 
Dünya konulup göçülen bir han gibidir. Yolcu gider han kalır:

Dünya ribâtında çün yolcu konuksun bugün

Tanla göçüp gidicek kala yerinde ribat

(Şeyhî Divanı G87/6)

Dünya misafirhanesinin daha temeli atılmadan aşk yolunun çileli bir yol olduğu bellidir.

Şâh-râh-ı 'aşkda câna konardı derd ü gam

Dahı bünyâd olmamışdı dehr mihmân-hânesi

(Yahyâ Divanı G437/4)

Dünya, Hakk'ın tecelli noktasıdır:

Hüsn ma'nîsine bu cân u cihân sûrettir

Yüzün âyînesi ol sûrete ma'nî mi değil

(Şeyhî Divanı G106/4)

Dünya cefa çektiren bir deve benzer, onun verdiği bu cefaya tahammül edilmelidir; çünkü bu, herkesin cefadan nasibini aldığı bir hikâyedir:

Şeyhî bu dîv-i dehr cefâsın tahümmül et

Bir kıssadır bu gussa ki her ins ü cân çeker

(Şeyhî Divanı G58/7)

Dünya bir gaflet uykusu, geçici bir rüya, bir görüntüler âlemidir:

Hâb ü hayâl-i gafleti 'âlem sanır gören

Mir’ât içinde sûret-i âdem sanır gören

(Şeyh Gâlib Divanı G245/1)

Sûret-i ikbâl-i dünyâ aldatır gâfilleri

'Işret anlarlar anı Yahyâ hayâl-i hâb iken

(Yahyâ Divanı G272/5)

Dünya, yanına yaklaşılmayan, girdaplarla dolu bir denizdir:

Hîç revâ mıdur gam-ı dünyâya düşmek ey gönül

Bir kenârına erilmez bahr-ı pür-gird-âb iken

(Yahyâ Divanı G272/4)

Dünya bir geçit, bir boğaz gibidir:

Geldün çü bu tengnâ-yı dehre

Mahlas ide gör Ali Rızâ'yı

(Yahyâ Divanı K5)

Geçici zevklere aldanan gönül için dünya, günün gün edildiği bir oyun yeridir:

Güler oynardı dil bâzîçegâh anlardı dünyâyı

Kanı ol şevkler ol üns ü hâletler o âlemler

(Yahyâ Divanı G117/2)

Bu dünya vefa tohumunun ekilmediği, safanın derilmediği ve sevincin de hasıl olmadı̆̆ı bir ekin tarlasıdır:

Vefâ tohmı ekilmez mi bu 'âlem kiştzârında 
Yerine göre de dünya, âb-ı hayatın arandığı zulmetler âlemidir:

Bu dehr zulmetinde ger âb-ı Hızır gerek

Câm-ı cihân-nümâyile 'ayş-ı Sikender et

(Şeyhî Divanı G9/4)

Bazen de dünya, sevgilinin güzelliği ile anlam bulan ve her bir harfi bin kişiye ders olan bir sayfaya benzetilerek olumlu özellikleriyle ele alınır:

Cihân hüsnü yüzünden bir varaktır

Ki her bir harfi bin câna sebaktır

(Şeyhî Divanı G3o/1)

Muhabbet meyini içenlerin safa bulduğu bir meyhaneye; neşe tedarik edilmek istenen bir içki meclisine benzetilen dünya, geçici zevklerin tedarik edilmesi noktasında da olumlu bir anlam taşır:

Humhâne-i cihânda mahabbet meyin içen

Sâfi safâ bulan durur ayrugı dürdden

(Şeyhî Divanı K7/23)

Şikeste bir sifâl olsun nemiz var sâgar-ı Cemde

Garaz bir neş'e tahsîl eylemekdür bezm-i 'âlemde

(Yahyâ Divanı G335/1)

Metinlerden hareketle dünyanın; viran, köhne bir saraya, geçici bir pazar yerine, bir hana, hankâha, kocakarıya, efsaneye, yedi başlı ejderhaya, gül bahçesine, dikenliğe, hazineye, deve, meyhaneye, rüyaya, görüntüler âlemine, denize, oyun yerine, ekin tarlasına benzetilerek geçici güzelliklerle aynı zamanda gam ve kederle dolu, aldatıcı bir mekân olduğuna dikkat çekilmiştir. Bunların dışında âlem olarak da adlandırılan dünya, şairler tarafından Allah'ın tecelli ettiği bir varlık, bir ayna olarak değerlendirilmiştir. Bir misafirhane olan dünyada insan geçici bir mekânda olduğunun farkına varmalı ve ona göre davranmalıdır. Aynı zamanda İlahî güzelliğin bir yansıması olarak değerlendirildiğinde de özellikle arifler tarafından dünya, ibretlerle ve sırlarla dolu bir mekân halini almaktadır. Onun için uçsuz bucaksız ve sonu hüsran olan dünya denizinin her bir zerresinde Allah'ı ve onun güzelliklerini görebilmek insanın vazifesi olmalıdır. İşte bu anlayışla da dünya terimi, genelde şairler tarafından daha çok dinî ve tasavvufî bakış açısıyla değerlendirilmiştir.

\section{Dünyanın nitelikleri}

İnsan ve dünyanın yaratılış sebebi "lâ ilâhe illallâh" sırrının mazharı olmaktır:

'Âlem ü âdemin zuhûru nedir

Mazhar-ı lâ ilâhe illallâh

(Şeyhî Divanı K1/5)

Dünya sebatsızdır, kararsızdır, temelsizdir, vefasızdır ve dünyanın bu hallerine vakıf olmak gerektir:

Ey pây-bend-i dâmgeh-i kayd-ı nâm u neng

Tâ key hevâ-yı meşgale-i dehr-i bî-direng

(Bâkî Divanı Mer.1/1)

Gam çeken mâl ü metâ' -1 dehr-i bî-bünyâd içün

Neydügin bilse me’âl-i hâl-i dünyâ kâşkî

(Bâkî Divanı G496/4) 
Rûy u mûy-ı yâre benzer nesne dahı görmedüm

Gerçi gördüm bî-vefâ dünyâda nice mâh u sâl

(Bâkî Divanı G293/2)

Misafir olunan bu cihandan adalet ummak, dört dörtlük bir saadet beklemek doğru değildir:

Dört üstü dört olur mu safâ bu cihânda kim

Merbût-ı çarmîh-i anâsır bulunmuşuz

Dâd alma mümkün idi felekde yâ neyleyim

Birkaç zamân içinde müsâfir bulunmuşuz

(Şeyh Galib Divanı G126/3, 4)

Dünyada mutluluk ve üzüntü; iyi ve kötü; gam ve ferah; varlık ve yokluk iç içedir:

Gehî vuslatda 'âşık gâh mehcûr

Bu dünyâdur gehî mâtem gehî sûr

(Bâkî Divanı G132/4)

Câm-ı cihân-nümân yüzüni pâk tut müdâm

'Âlemde nîk ü bed ferah u gam gelir gider

'Âşık gerek ki sıdk ile sâbit-kadem dura

Yoksa hezâr-bâr bu 'âlem gelir gider

(Şeyhî Divanı G52/3, 4)

Gamm-ı dil tagyîr-i vaz' itse eger devr-i zamân

Her kişi dünyâda geh mahzûn olur geh şâd-mân

(Bâkî Divanı KT19/2)

Hep müsâvî görünür bûd u nebûd-ı 'âlem

Ben terâzûya vücûd u 'ademin çok çekdim

(Şeyh Gâlib Divanı G223/3)

Cihân-ı bî-sebât içre gam u şâdî berâberdir

Eger şâd olmadunsa gam degül Yahyâ hazîn olma

(Yahyâ Divanı G312/5)

Dünyanın cefa ve sıkıntısı sadece gönül aynasını değil İskender'in dünyayı gösteren kadehini bile kırar:

Seng-i cefâ-yı dehr ile mir'ât-ı dil degül

Câm-ı cihân-nümâ-yı Sikender şikest olur

(Bâkî Divanı G98/4)

Dünya geçicidir, gününü gün etmek gereklidir:

Sâkî mey-i Bâkî'yi getür bezme safâ vir

Çün kâr-ı cihân 'âkıbetü'l-emr fenâdur

(Bâkî Divanı G1o6/7)

Dünyanın süsleri, ziynetleri su üzerindeki resim gibidir ve bu geçici süslere meftun olmamalıdır:

Bilirken bî-bekâ olduğun âb üzre olan nakşın

Bu meftûnluklara ârâyiş-i dünyâ mıdır bâ'is

(Yahyâ Divanı G34/3) 
Bu geçici âlemin ömrü tıpkı kısa bir gezintiye benzer bundan dolayı gam çekmek yersizdir:

Eglenilmez diyü gam çekme bu fânî dünyede

Tut ki bâg-ı 'âleme seyrâna geldün ey gönül

(Yahyâ Divanı G219/3)

Bu sonu yokluk olan dünyanın hallerini içindeyken kimse anlayamaz:

Hep cân atıyor halk fenâ mülküne ammâ

Bir hârice çıkmaz ki ne halet var içinde

(Şeyh Gâlib Divanı G296/2)

Zira görünüşte süslü olan bu dünya, sonunu göstermeden insanı aldatır:

Seni bir sûret-i zîbâ ile aldar ammâ

'Âkıbet sana ne yüz göstere dünyâ göresin

(Bâkî Divanı G384/6)

Bu geçici dünya bir tek onun hallerini bilen ehl-i irfanı ortadan kaldıramaz:

Felekler farkına basdı kadem devründe fazl ehli

Nice pâ-mâl ide dünyâ-yı fânî ehl-i 'irfânı

(Bâkî Divanı K5/18)

Dünya alçaktır, onun önünde baş eğmemek gereklidir; zira tevekkül, güven hep Allah'adır:

Geç otur sedd-i Sikender gibi künc-i 'uzlete

Başun egme dehr-i dûnun efser-i Dârâsına

(Bâkî Divanı G408/6)

Baş egmezüz edânîye dünyâ-yı dûn içün

Allâhadur tevekkülümüz i'timâdumuz

(Bâkî Divanı G192/2)

Dünya halas olunamayan engellerle dolu bir mekândır:

Kemend-endâz-ı dehrün kimse bendinden halâs olmaz

Zamâne gösterür Behrâm olursan 'âkıbet gûnı

(Bâkî Divanı G484/5)

Dünya kimine safa, zevk ve eğlence yeri kimine de gamlı bir zindan olacak kadar zıt özelliklere sahiptir:

Bu cihân kimine kasr-ı tarâb u 'ayş u safâ

Kiminün mihnet ile başına zindân ancak

(Bâkî Divanı G238/3)

Dünyanın geçiciliği ve faniliğine en güzel örnekler efsanevi kahramanların sonudur. Tıpkı İran şahları Dârâ ve Behram'da ${ }^{6}$ olduğu gibi:

Devlet-i dâr-ı cihân devr-i zamân ey Bâkî

Pâydâr olmadugın kıssa-i Dârâdan bil

(Bâkî Divanı G299/5)

Cihân mülkinden ey Bâkî ne hasıl

Bilürsin behre-i Behrâm-ı Gûrı

(Bâkî Divanı G511/5)

Behram'ın bir av esnasında yaban eşeği kovalarken bir çukura düşüp öldüğü (Pala, 2014: 63); Dârâ'nın da İskender'in bir hilesi sonucu mabeyincisi tarafından zehirlenerek ödürüldüğü (Pala, 2014: 106) rivayet edilir. 
Sıkıntı ve eziyet ile dolu dünyanın hiç vefası yoktur:

Dehr-i pür-kahrla mihr ile vefâ yokdur hîç

Bir nefes câmdır ancak gönül ârâm-gehi

(Şeyhî Divanı G197/5)

Ayrıllğı̆n sıkıntısı ve dünyanın karmaşasından kurtulmanın tek yolu ölümdür:

Uçurdum murg-ı cânı âşiyân-ı 'âlem-i tenden

Halâs oldum gam-ı hicrân ile gavgâ-yı 'âlemden

(Yahyâ Divanı G296/1)

Alçak dünya, sahte süs ve yaldızlarla doludur, onun güzellikleri insanı aldatmamalıdır:

Dünyâ-yı denî kim toludur nakş-ı muzahref

Aldamasun inende seni hüsn ü behâsı

(Şeyhî Divanı K6/7)

Dünya, kişiyi gerçek güzelliği seyretme işinden alıkoyabilecek bir değere ve öneme sahip değildir. Bitip tükenmez bir kavga yeridir:

'Âlem dedigin senin ne manâ bilsem

Bitmez mi tükenmez mi bu gavgâ bilsem

Bir şâm u seherdir ki mükerrer dâim

Olduk ne için mahv-ı temâşâ bilsem

(Şeyh Gâlib Divanı R/44)

Dünyada var olan her şey aslında yoklukta gizlidir, tek var olan şey Hakk'tır:

Yokdur nazar olsa bu cihânda ne ki var

Var yokdan olup yokluga geldi tekrâr

Var var bula gör anı ki yok yok Allâh

Yoklukda bulundu yog imiş var ise yâr

(Şeyh Gâlib Divanı R/46)

Dünya Hakk'ın tecelligâhıdır ve içinde nice gizemler, sırlar taşımaktadır:

Cihânda nice sır var kimse bilmez

Bilinmek olsa da farza denilmez

(Şeyh Gâlib Divanı G112/1)

Âlemin mahiyeti neyin hoş sedasında gizlidir, ney gurbetteyse dünya gurbetin ta kendisidir:

Dinle nây-ı hoş-sadâyı anla 'âlem neydigin

Nâle-i 'uşşâkdan fehm eyle âdem neydigin

(Yahyâ Divanı Müf. 67)

İyi-kötü, güzel-çirkin, varlık-yokluk gibi zıt unsurları içinde barındıran dünya kararsızdır ve sürekli değişim içerisindedir. Dünya misafirhanesi fanidir ve bu fani âleme insan gönül vermemelidir. Şairler ise bu durumu ve dünyaya karşı takınılması gereken tavrı şöyle dile getirir:

\section{Dünyaya karşı takınılması gereken tavır}

Bâkî, kendisine vefasız dünyaya meftun olmamayı öğütler; zira dünya göründüğü gibi değildir:

Dehre meftûn olma ey Bâkî felek râm oldı tut

\footnotetext{
Adres | Adress 
Bî-vefâ dünyâ hele ben bildügüm dünyâ mıdur

(Bâkî Divanı G123/5)

Akıllı olan, mert olan dünyanın güzelliklerine aldanmaz; çünkü dünyadan kimse bir kazanç sağlamamıştır:

İşve-i dehre gönül virmez o kim 'âkildür

Almadı behre begüm kimse bu dünyâdan bil

(Bâkî Divanı G299/4)

Gerçek erdir bakmayan nakş-ı nigâr-ı 'âleme

Mâ'il-i ârâyiş-i dünyâ degilsen merdsin

(Yahyâ Divamı G290/3)

Ahiretin huzurlu, güvenli menziline varmak için dünyanın güzelliklerinden feragat etmek gerektir, mutluluk uzlet erbabındadır:

Menzil-i âsâyiş-i 'ukbâya istersen vüsûl

Hubb-i dünyâdan ferâgat gibi olmaz togrı yol

Şâdmân erbâb-ı 'uzletdür hemân Bâkî melûl

Ger huzûr itmek dilersen ey Muhibbî fârig ol

Olmaya vahdet makâmı gûşe-i 'uzlet gibi

(Bâkî Divanı T4/V)

Dünya devletinin ömrünü kıskanmamak lazımdır, dünya gaflet uykusu içerisindeki kısa bir rüya gibidir:

Reşk itme 'ömr-i devlet-i dünyâya Bâkîyâ

Kim hâb-ı gaflet içre hemân bir hayâldür

(Bâkî Divanı G96/5)

Devlet-i dünyâ hayâl-i hâba benzer nesnedür

Baht-ı bî-dâr isteyenler terk-i hâb itmek gerek

(Bâkî Divanı G256/3)

Dünya devleti için gamlı ve mutlu olmak yersizdir; çünkü dünyanın halleri değişkendir:

Devlet-i dünyâ içün hergiz ne gam-gîn ol ne şâd

Ber-karâr olmaz bilürsin hâl-i 'âlem ey göñül

(Bâkî Divanı G3oo/3)

Akıllı olan kişi geçici olan dünya malı ve geçici maddî nimetler ile gururlanmamalıdır:

Âkil oldur gelmeye dünyâ metâ'indan gurûr

Müddet-i devr-i felek bir demdür âdem bir nefes

(Bâkî Divanı G211/4)

Al gönlümü âyîne-i manâdır bu

Senden bana bir sûret-i ranâdır bu

Hattın gelip ey mâh utanırsın bir gün

Hüsnünle gurûr etme ki dünyâdır bu

(Şeyh Gâlib Divanı R31)

Dünya rahat yüzünün olmadığı bir gamhanedir, bu alçak dünyanın talibinin bu gaflet uykusundan uyanmasi gerektir:

Hâb-ı gaflet nice bir ey tâlib-i dünyâ-yı dûn 
Var ise râhat yiri sandun bu mihnet-hâneyi

(Bâkî Divanı G509/5)

Önü sonu yokluk olan dünyayı boş vermek gerektir; zira bu yokluk içinde tek varlık sevgilidir:

Sâkî beri sun şarâb-ı bâkî

K'uram kademinde arşa sâkı

Ne râh durur bu râhat-efzâ

Kim ruha verir hayât-ı bâkî

Ne şerbet olur ki lezzetinden

Cân zevkin alır gönül mezâkı

'Âlem dolu fitnedir edelden

Kaşın gözün ile ittifâkı

Âhım feleğe bir od bırakdı

K'irürdü güneşe ihtirâkı

Taşın içi taşa dağıla dă̆

Yazsam gam u şerh-i iştiyâkı

Bununla ki tâkatüm durur tâk

Döymez gücüme cihân nitâkı

'Âlem ki önü sonu 'ademdir

Niçin kamu tâkı vü rivâkı

Cân ile cihân 'acûzesine

Bildinse bu remzi ver talâkı

Kim yok bu diyâr içinde deyyâr

Var iste ki yârdır ne kim var

(Şeyhî Divanı Mus.3/4)

Dünyanın önü sonu yokluktur ve onun için gam çekmek gereksizdir:

Seher gülşende âvâz-ı negamdır

Gel ey bülbül cihân için ne gamdır

Ganîmet gör vücûdun bir nefes kim

Hakîkat gözlesen 'âlem 'ademdir

(Şeyhî Divanı G33/1, 2)

Kâmil olan insan dünya sıkıntıları ile hem-hâl olmamalıdır:

Görün mâhı ki bedr olmayıcak noksân-pezîr olmaz

Muhassal cevr-i dehri çekmez illâ kim kemâl ehli

(Yahyâ Divanı G445/2)

Sevgili yerine dünyayı gözeten, âb-ı hayat yerine boş hayal peşinde koşan gibidir:

Der-i cânân koyup cihân gözeden

Âb-ı hayvânı kor serâba gider

(Şeyhî Divanı G48/6)

Yine dünyadaki her şey bir hayal gibidir ve batıl olan bu hayalin peşinden koşmak boş bir iştir: 
Hakkâ cihân içindeki cümle hayâldir

Bâtıl hayâle bunca muhabbet ne fâyide

(Şeyhî Divanı G151/6)

Alçak dünyaya âlimler dayanmaz. Onun bir rüzgâr gibi gelip geçtiğini ancak pak din olanlar anlar:

Dünyâ denî durur ana dânâ dayanmaya

Bâd anlayan bu hâki zihî pâk-dîn ola

(Şeyhî Divanı G157/4)

Gönül ehli dünya işlerine dalmamalıdır:

Dehrin iki kadehle degil kâr u bârını

Bilme cihân umûrunu rind-i cihân isen

(Şeyh Gâlib Divanı G182/4)

Beyitlerde de görüldüğü gibi şairler, boş bir hayal olan veya geçici bir heves olan bu dünyaya meyil verilmemesini ortak bir duygu ve düşünce ile dile getirirken gönül ehli olanların, Hak dostu olanların, âlimlerin ve kâmillerin bu boş hayalin peşinde gitmeyeceğini de vurgulamışlardır. "Dünyâ yok olup giden bir gölge, kul ile Mevlâ'sı arasında bir perdedir. Hakîki kul, onun sevgisinin zerresini bile kalbine koymaz (Erginli vd. 2006: 188)" Açıklaması da bunu doğrular niteliktedir.

\section{Sonuc}

Üzerinde çalışma yapılan divanlardan tespit edildiği kadarıyla dünya dikenlikten gül bahçesine, rüyadan gölgeye, acuzeden yllana-ejderhaya, viran bir saraydan bir ekin tarlasına kadar pek çok nesneye benzetilmiş ve bu benzetmeler aracıllğıyla da dünyanın olumsuz özelliklerine dikkat çekilmiştir. Ayrıca yeri geldikçe insanlara gerekli uyarılarda bulunulmuştur. Hemen hemen her zaman zemmedilen dünya, metinlerde dinî ve tasavvufî yönüyle ele alınmıştır. Şairler dünyanın vefasız, kararsız, temelsiz, adaletsiz, geçici süslerle dolu, aldatıcı ve göz boyayıcı şeklinde nitelendirilen olumsuz özelliklerine dikkat çekerken bu dünya hayatına aldanmayacak olanların basiret sahibi âlimler ve kâmiller olduğuna değinmişlerdir. Buna binaen bazı örnek beyitlerde de dünyanın Hakk'ın tecelligâhı olduğu vurgulanmış ve dünyanın manasının Allah'ta gizli olduğuna, onun için dünyanın süslerinin, güzelliklerinin, hatta eza ve cefasının iyi temaşa edilmesi gerektiğine, asıl vatan olan ahirete varmada dünyanın bir geçit olduğuna ve bu noktada dünya hayatının güzel değerlendirilmesi gerektiğine nasihat edasıyla dikkat çekilmiştir. Bu doğrultuda şu ifadeyi kullanmak mümkündür: Metinlerde kötülenen, uzak durulması tavsiye edilen dünya kişiyi Hakk'tan uzak tutan, onu ahiret amellerinden alıkoyan dünyadır. Gerçekte dünya güzelliklerle dolu bir mekândır; fakat bu mekân insanı Hakk'a yöneltme noktasında değerli bir hal almaktadır. Önemli olan da dünyadaki bu güzelliklerde Hakk'ı görebilmek, onun ayetlerini hissedebilmektir.

\section{Kaynakça}

Cebecioğlu, E. (1997). Tasavvuf Terimleri ve Deyimleri Sözlüğü, Ankara: Rehber Yayınları.

Çelebioğlu, Â. (1969). Mesnevî̀i Şerîf Ash ve Sadeleştirilmişiyle Manzum Nahîfi Tercümesi, C. 2, İstanbul: Sönmez Neşriyat.

Erginli, Z. (Ed.). (2006). Metinlerle Tasavvuf Terimleri Sözlüğü, İstanbul: Kalem Yayınları.

Erginli, Z. (2006). "Temel Tasavvuf Klasiklerinde Dünyâ Algısına Tolu Bir Bakış", Uludă̆ Ünversitesi İlahiyat Fakültesi Dergisi, C. 15, S. 2, s. 117-181.

Ertem, R. (1995). Yahyâ Divanı, Akçağ, Ankara.

İmam Gazâlî. (1989). İhyâu Ulûmi'd-dîn, (Çev. Ahmed Serdaroğlu), C. 3, İstanbul: Bedir Yayınevi. 
İmam Gazâlî. (2003). Kalplerin Keşfi, (Çev. Ali Kaya), İstanbul: Semerkand Yayınları.

İsen, M. , Kurnaz, C. (1990). Şeyhî Divanı, Ankara: Akçă̆ Yayınları.

İmam Nevevi. (2016) Riyâzü's-Sâlihîn, (Çev. Prof. Dr. M. Emin Özafşar, Prof. Dr. Bünyamin Erul), C. 1, Ankara: Diyanet İşleri Başkanlı̆̆ı Yayınları.

Kalkışım, M. (1994). Şeyh Gâlîb Divanı, Ankara: Akçă̆ Yayınları.

Küçük, S. (1994). Bâkî Dîvânı, Ankara: Türk Dil Kurumu Yayınları.

Schimmel, Annemarie. (2001). İslamın Mistik Boyutları, (Çev. Ergun Kocabıyı), İstanbul: Kabalcı Yayınevi.

Pala, İ. (2014). Ansiklopedik Divan Şiiri Sözlüğü, İstanbul: Kapı Yayınları.

Tatcı, Mustafa. (2012). Dîvân-ı İlâhîyât, İstanbul: Kapı Yayınları.

Uludă̆, S. (1994). "Dünya" DİA, C.10, Türkiye Diyanet Vakfı İslâm Araştırmaları Merkezi, s. 22-25

Yetik, E. (1992). "Mevlânâ'nın Dünya Görüşü ve Topluma Bakışı" Ondokuz Mayıs Üniversitesi İlahiyat Fakültesi Dergisi, S: 6, s. 101-108.

Yusuf Has Hacip. (2008). Kutadgu Bilig, (Çev. Reşid Rahmeti Arat), İstanbul: Kabalcı Yayınevi, 2. Basim.

http://www.tdk.gov.tr E. T: 15.01.2019

https://kuran.diyanet.gov.tr/tefsir E. T: 10.01.2019 